\title{
Assessment of Remaining Recoverable Oil in Selected Major Oil Fields of the San Joaquin Basin, California
}

\begin{abstract}
he U.S. Geological Survey (USGS) recently completed an estimate of volumes of technically recoverable, conventional oil that could eventually be added to reserves in nine selected major oil fields in the San Joaquin Basin in central California. The mean total volume of potential oil reserves that might be added in the nine fields using improved oil-recovery technologies was estimated to be about 6.5 billion barrels of oil.
\end{abstract}

\section{Introduction}

A team of U.S. Geological Survey (USGS) scientists recently completed an assessment of potential additions to oil reserves that could result from improved oil-recovery technologies in selected large oil fields in the San Joaquin Basin oil and gas province in central California. The basin is bounded on the east by the Sierra Nevada, on the north by the Stockton Arch, on the southwest by the Temblor Range, and on the south by the San Emigdio and Tehachapi Mountains. Oil and gas development in the San Joaquin Basin began in the late 1800s, and the basin came to be recognized as one of the largest petroleum provinces in the United States. The basin contains 21 oil fields in which known recoverable oil (cumulative production plus proved reserves) exceeds 100 million barrels of oil (MMBO), including 3 of the 10 largest fields in the Nation (Midway-Sunset, Kern River, and South Belridge).

Recent decades have been a time of exceptional development in existing fields of the San Joaquin Basin. In the 1960s, introduction of thermal recovery technologies (application of steam technology) caused abrupt and substantial additions to reserves in fields that contain heavy oil (American Petroleum Institute (API) gravity less than 20 degrees). Similar additions to reserves have continued to the present. During the 1980s, reserve additions began to be made using hydraulic fracturing in Monterey Formation diatomites (sedimentary rock made up of the tiny silica skeletons of diatoms) on the west side of the basin. These additions have increased as production from diatomite replaces declining,

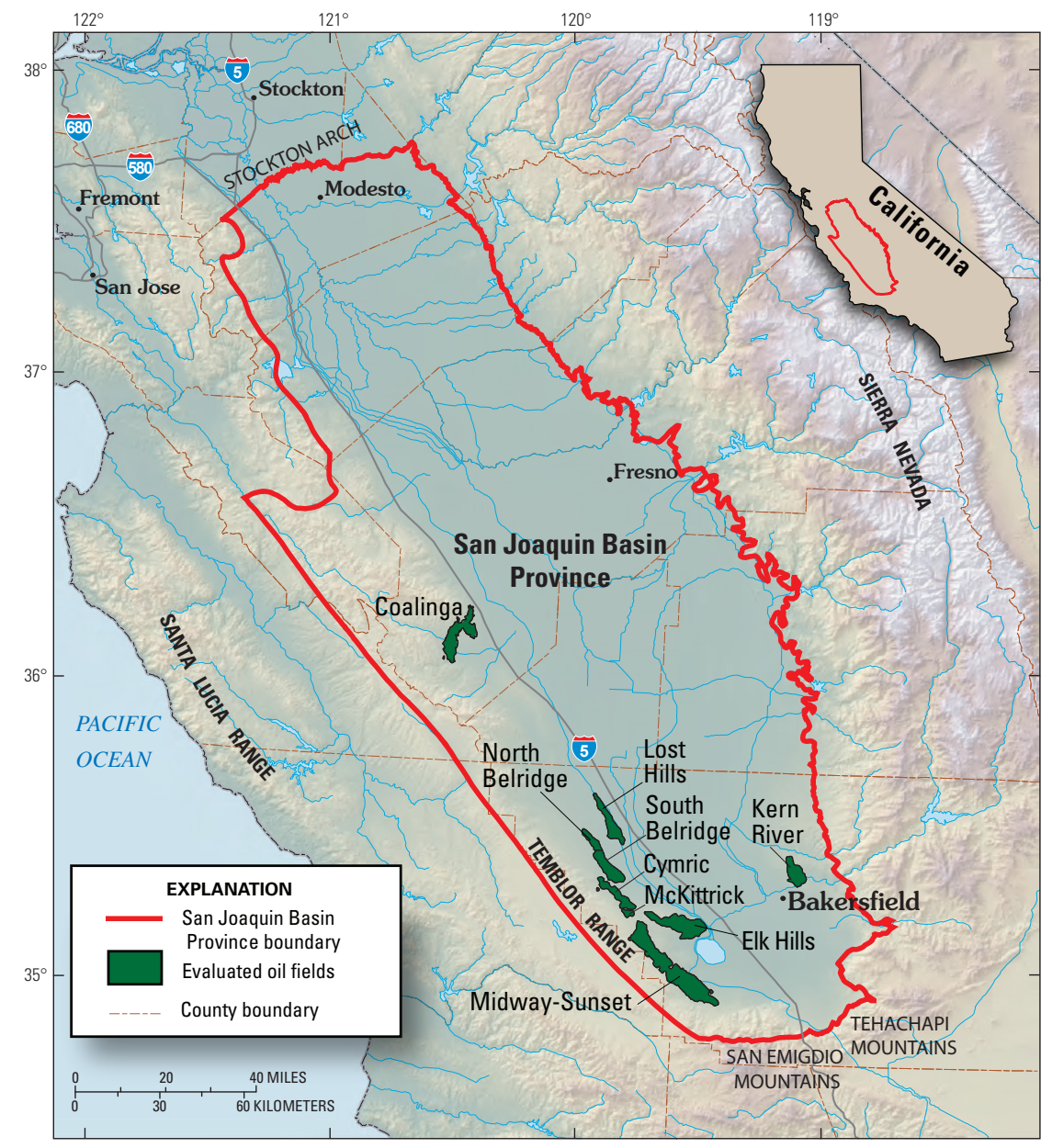

Map of San Joaquin Basin oil and gas province in central California, showing oil fields evaluated for this study.

but still substantial, production from overlying steam-flooded reservoirs. Since 1965, more than 8 billion barrels of recoverable oil have been added to reserves within existing fields. These additions have significantly extended the life of California oil production and slowed the decline of U.S. domestic production.

\section{Methodology}

Nine oil fields were studied, most of which have shown significant additions to reserves in the last several decades. Production and reserves information came from the California Division of Oil, Gas, and Geothermal Resources. To assess the potential for future additions to reserves, an evaluation was made of each field (Klett and others, 2011). The geology of each field was analyzed, and its development history was reviewed. Estimates of original oil in place (OOIP) in each field were based on evaluation of information from various published and proprietary sources. Potential growth of reserves was evaluated by estimating the range of recovery efficiency that might be realized with existing technology, based on levels of recovery efficiency that have (1) been achieved in analogous reservoirs, (2) modeled in engineering studies, or (3) indicated by laboratory results reported in technical literature. For each reservoir analyzed, 
Key assessment data for oil fields individually assessed within the San Joaquin Basin, California.

[MMBO, million barrels of oil (BBO, billion barrels of oil; $1 \mathrm{BBO}=1,000 \mathrm{MMBO}$ ); OOIP, original oil in place. Estimated recovery efficiency is potentially recoverable proportion of OOIP. Known recoverable oil is cumulative production plus reserves at the end of 2006, from California Division of Oil, Gas, and Geothermal Resources (2007)]

\begin{tabular}{|c|c|c|c|c|c|c|c|c|}
\hline \multirow[t]{2}{*}{ Field } & \multirow[t]{2}{*}{ Reservoir(s) } & \multirow{2}{*}{$\begin{array}{c}\text { Known } \\
\text { recoverable oil } \\
\text { (MMBO) }\end{array}$} & \multicolumn{3}{|c|}{$\begin{array}{l}\text { Estimated 00IP } \\
\text { (MMBO) }\end{array}$} & \multicolumn{3}{|c|}{$\begin{array}{c}\text { Estimated recovery efficiency } \\
\text { (percent) }\end{array}$} \\
\hline & & & $\min$ & med & $\max$ & $\min$ & mode & $\max$ \\
\hline Coalinga & Temblor reservoir & 965 & 3,000 & 3,500 & 5,000 & 30 & 45 & 65 \\
\hline \multirow[t]{3}{*}{ Cymric-Welport Area } & Diatomite reservoir & 163 & 425 & 600 & 1,000 & 25 & 40 & 55 \\
\hline & Pre-Monterey reservoirs & 36 & 145 & 175 & 210 & 30 & 40 & 55 \\
\hline & Tulare reservoir & 339 & 550 & 700 & 1,000 & 55 & 65 & 85 \\
\hline \multirow[t]{2}{*}{ Elk Hills } & Stevens/Monterey and older reservoirs & 784 & 2,300 & 2,700 & 3,500 & 35 & 40 & 50 \\
\hline & Shallow Oil Zone & 601 & 1,300 & 1,600 & 2,000 & 45 & 48 & 55 \\
\hline Kern River & All reservoirs & 2,451 & 3,400 & 3,600 & 4,200 & 70 & 75 & 85 \\
\hline \multirow[t]{2}{*}{ Lost Hills } & Diatomite and older reservoirs & 103 & 2,000 & 2,800 & 4,500 & 20 & 35 & 55 \\
\hline & Tulare-Etchegoin reservoir & 374 & 655 & 700 & 1,500 & 45 & 55 & 65 \\
\hline McKittrick-Main Area & All reservoirs & 203 & 525 & 800 & 1,700 & 40 & 50 & 60 \\
\hline \multirow[t]{2}{*}{ Midway-Sunset } & Diatomite reservoirs & 21 & 300 & 1,500 & 3,000 & 10 & 20 & 40 \\
\hline & All reservoirs except diatomite & 3,436 & 6,400 & 8,000 & 12,000 & 45 & 60 & 70 \\
\hline \multirow[t]{3}{*}{ North Belridge } & Diatomite reservoir & 71 & 400 & 600 & 1,000 & 25 & 40 & 55 \\
\hline & Temblor and older sandstone reservoirs & 70 & 300 & 350 & 500 & 25 & 30 & 40 \\
\hline & Tulare-Etchegoin reservoir & 22 & 50 & 100 & 300 & 45 & 55 & 65 \\
\hline \multirow[t]{2}{*}{ South Belridge } & Diatomite reservoir & 710 & 2,500 & 5,000 & 8,000 & 25 & 40 & 55 \\
\hline & Tulare reservoir & 1,273 & 1,650 & 1,900 & 2,200 & 65 & 75 & 85 \\
\hline
\end{tabular}

ranges of OOIP and potential recovery efficiency were estimated. Those values were used in "Monte Carlo" computer simulations to generate estimated ranges of oil volumes technically recoverable from each reservoir, without regard to economic constraints.

\section{Results}

On the basis of the analysis of recovery efficiencies and remaining oil in place, the USGS estimates that at least 3.6 additional billion barrels of oil (BBO) may be recovered from the fields studied in the San Joaquin Basin, in addition to cumulative production plus proved reserves as of 2006. The mean estimate is that an additional $6.5 \mathrm{BBO}$ could be recoverable. Under extremely favorable but unlikely circumstances, reserve additions could approach 10 BBO. Much of the potential reserves could come from improved recovery in diatomite reservoirs of the Monterey Formation, given continued technological evolution. Additional volumes of oil could come from continued application of thermal-recovery technologies to shallow reservoirs containing heavy oil, although the oil remaining in such reservoirs is more difficult to recover than in similar reservoirs already exploited. In a few reservoirs, particularly deep sandstone reservoirs containing relatively light oil such as sandstone reservoirs within the Monterey Formation at Elk Hills field, additional oil could be recovered with injection of carbon dioxide.

Oil reserves will also continue to be added in fields within the San Joaquin Basin that were not included in this analysis. Most such fields are smaller than the fields studied, and their additions to reserves will also be smaller, although they may be significant. Statistical methods, like those

\section{Assessment results for volume of additional oil potentially recoverable from selected oil fields in the San Joaquin Basin, California (technically recoverable resources).}

[Mean estimates add to a total mean, but fractile values for individual fields are not additive; fractiles (nonadditive) for the entire group of fields are shown in the bottom row highlighted in yellow. MMBO, million barrels of oil (BBO, billion barrels of oil; $1 \mathrm{BBO}=1,000 \mathrm{MMBO}$ ). F95 denotes a 95-percent chance of at least the amount tabulated, F-50 denotes a 50-percent chance, and F5 denotes a 5-percent chance. A negative value indicates a chance that reserves could decrease from currently estimated values]

\begin{tabular}{|c|c|c|c|c|c|}
\hline \multirow{2}{*}{ Field } & \multirow{2}{*}{ Reservoir(s) } & \multicolumn{4}{|c|}{ Oil (MMBO) } \\
\hline & & F95 & F50 & F5 & Mean \\
\hline Coalinga & All reservoirs & 239 & 676 & 1,252 & 705 \\
\hline \multirow[t]{3}{*}{ Cymric-Welport Area } & Diatomite reservoir & 1 & 77 & 191 & 84 \\
\hline & Pre-Monterey reservoirs & 21 & 36 & 56 & 37 \\
\hline & Tulare reservoir & 40 & 139 & 284 & 148 \\
\hline \multirow[t]{2}{*}{ Elk Hills } & Stevens/Monterey and older reservoirs & 164 & 342 & 589 & 355 \\
\hline & Shallow Oil Zone & 73 & 188 & 327 & 193 \\
\hline Kern River & All reservoirs & 97 & 315 & 624 & 332 \\
\hline \multirow[t]{2}{*}{ Lost Hills } & Diatomite and older reservoirs & 556 & 917 & 1,451 & 951 \\
\hline & Tulare-Etchegoin reservoir & -41 & 18 & 174 & 35 \\
\hline McKittrick-Main Area & All reservoirs & 79 & 197 & 447 & 221 \\
\hline \multirow{2}{*}{ Midway-Sunset } & Diatomite reservoirs & 112 & 311 & 637 & 335 \\
\hline & All reservoirs except diatomite & 238 & 1,229 & 2,718 & 1,320 \\
\hline \multirow[t]{3}{*}{ North Belridge } & Diatomite reservoir & 89 & 168 & 286 & 176 \\
\hline & Temblor and older sandstone reservoirs & 20 & 41 & 73 & 43 \\
\hline & Tulare-Etchegoin reservoir & 10 & 33 & 90 & 39 \\
\hline \multirow[t]{2}{*}{ South Belridge } & Diatomite reservoir & 460 & 1,234 & 2,242 & 1,278 \\
\hline & Tulare reservoir & 46 & 222 & 421 & 226 \\
\hline All evaluated fields & All evaluated reservoirs & 3,517 & 6,326 & 9,955 & 6,478 \\
\hline
\end{tabular}

Reserve Growth Assessment Team: Marilyn E. Tennyson, Troy A. Cook, Ronald R. Charpentier, Donald L. Gautier, Timothy R. Klett, Mahendra K. Verma, Robert T. Ryder, Emil D. Attanasi, Philip A. Freeman, and Phoung A. Le

Edited by James W. Hendley II Graphic design by Stephen L. Scott

\section{For Further Information}

Supporting geologic studies of total petroleum systems and assessment units and reports on the methodology used in this assessment, as well as the assessment results, are available at the USGS Energy Resources

Program Web site: http://energy.usgs.gov/ or contact

Marilyn E. Tennyson (tennyson@usgs.gov)

This Fact Sheet and any updates to it are available online at

http://pubs.usgs.gov/fs/2012/3050/ 